\title{
THE FEATURES OF POLITICAL PARTICIPATION IN CONDITIONS OF INFORMATION SOCIETY
}

\begin{abstract}
In the $21^{\text {st }}$ century, the Internet and information technologies form new opportunities for political participation. The Internet wide coverage has created unprecedented opportunities for dissemination of information on social-political processes, for enlargement of the aware sector and for their active involvement in social-political processes.

Use of the Internet in politics leads to the evolution of the conventional model of political participation, thus, securing the impact of broad masses on the political decision-making processes.

Political Internet participation makes it possible to overcome such obstacles as time and distance. The political discourse that had acquired features of horizontal communication is turning into a multicomponent, multi-lateral model of interactive communication.

The article presents the role and influence of the Internet and means of electronic communication on political ongoings and participatory processes. An analysis is given on the role of the Internet and information technologies in the revolutionary events and power turnover processes of 2018 in Armenia.

The author comes to the conclusion that neutralization of abuses and risks of the opportunities given by continually developing technologies, supposes not only philosophical consideration but also moral and legal studies and practical mechanisms.
\end{abstract}

Keywords: information technology, political participation, internet, social network, information society.

Under information society, the Internet and information technologies form a new platform and opportunities for political participation. Wide coverage of the Internet, mobilification have made it possible for broad social layers to be more informed and more or less involved in political processes. Currently, the Internet is employing a specific function: from a passive addressee of information, a user is transforming into an information developer and is becoming a subject of internet communication. The Internet forms an environment, a unique social space for the active sector of the society to present their initiatives and implement projects, such as fundraising for the solution of various issues, for collecting signatures, social actions, and so on.

Swift enlargement of the Internet coverage has opened unprecedented opportunities for the dissemination of information about social-poitical processes, for the increase of the informed portion and for its active involvement in socialpolitical processes.

Comprehensive transformations due to the development of technology, unlimited access to 
information resources are typical for post-industrial or more typical for information society (Sargsyan, 2008, p. 9).

Internet space is viewed as a special sphere of social life.

Active implementation of the virtual space to impede and to activate political participation in Armenia has become a serious factor during the last decade. This phenomenon achieved its pinnacle during the spring and summer months of 2018.

The aim of the present survey is to reveal the role and significance of the Internet and electronic communication in the revolutionary events and power turnover in Armenia in 2018.

Still, in 1996, Lawrence K. Grossman (1995) (former president of NBC News and former president of the Public Broadcasting System) predicted that the Internet would give wide opportunities to involve the public in the decision-making process (p. 290). Grossman's predictions are coming true in the $21^{\text {st }}$ century.

John Barlow in his "A Declaration of the Independence of Cyberspace" in a figurative way condensing the processes taking place around the world said: "In our world, who wants and wherever wants, can express his thoughts, no matter how unusual they are, without fear that they will be forced to keep silent or to agree with the majority. ... In our world, everything that creates human thought can reproduce and dissolve endlessly without paying any price". It's about cyberspace (Barlow, 1996).

Wide coverage of the Internet has resulted in a new method of political participation - political participation via the use of Internet resources.

Political participation through the Internet means involvement of various groups via information technologies in political processes, as well as in presentation by the authorities of positions and proposals concerning issues of public importance, ways to resolve them, projects concerning them, or in taking decisions through formation of public mood and opinion, in influencing the processes aiming to enforce these decisions.

Voynov D. A. offers to classify forms of political participation through the use of Internet resources following the traditional classification of forms of political participation. Conventional and non-conventional forms of political participation are singled out here. Conventional political participation is implemented in compliance with legal norms and procedures set in a definite political system. Non-conventional participation occasionally breaks these norms and is displayed via direct actions, bypassing representative institutions. Besides, some forms of internet communication activities can be classified among methods of political protest, which differ from nonconventional ones merely because don't presume immediate physical impact (Voynov, 2016, p. $50)$.

Conventional forms of political participation on the Internet include:

1. voting at Internet elections, polls, referenda;

2. creation and dissemination of political information through blogs, websites, Internetpapers, etc.;

3. fund-raising to support a party or movement;

4. participation in discussions of political issues in certain blogs, websites, teleconferences of political parties (movements), Internet communities, state bodies.

Non-conventional forms include:

5. hackers' attacks on citizens' websites, portals of state bodies, political parties and others; 
6. such political provocations as technologies of "black PR" (creation of clone-sites, dissemination of false information) (Voynov, 2016, p. 50).

There are different meetings and ways of classifying political participation in political literature: orthodox and unorthodox, elemental and organized (Vasilik, 2000, pp. 213-214), latent (non-explicit, unspecified) and explicit, individual and collective, legitimate and unlawful (Ekman \& Amna, 2012, p. 289).

Chadwick A. and May C. (2003) consider it expedient to divide political activeness on the Internet into three groups: managerial, consultative and participatory (p. 276).

Within the managerial model of internet participation, the process of involving Internettechnologies is viewed solely as improvement of traditional technologies implemented to update employment of state capabilities and allowing to "combine high speed of making decisions at low cost" (Chadwick \& May, 2003, p. 276). Information flow is linear (top to bottom). The main aim of communication is the reduction of bureaucracy and expenses, provision of information to citizens.

The administrative model presumes wide opportunities to consider citizens' opinions on issues of public importance in the process of taking political-administrative decisions. Even though this model promotes certain efficiency of state policy (as public opinion is taken into consideration while taking decisions), the information flow, just as in the previous model, is vertically organized - top to bottom - and the information space is strictly regulated by the state. In other words, citizens can voice their opinion only on matters identified by the government. According to Chadwick A. and May C., the administrative model is a transitory one between the managerial and participatory models combining their main characteristics: participation of citizens in the process of taking political decisions and management of the information agenda.

Finally, the participatory model characterizes multi-faceted, horizontal and multi-direction interrelations between citizens and politicians. Its main advantage is that its format supposes organization of contacts not only at layers citizencitizen and government-citizen but also the existence of well-established feedback communication from citizens to the state. The participatory model presumes that governments should be open for dialogue with citizens and organized groups.

Whatever the bases and forms for the classification of political participation, they are all exposed to the impact of IT, gaining new qualities and modernity.

In general, the following options of political activity and participation via the Internet are distinguished:

- voting at Internet elections, polls, referenda;

- creation and dissemination of political information through blogs, websites, Internetpapers, etc.;

- fund-raising to support a party or political movement;

- participation in discussions of political issues in blogs, websites of different political organizations;

- hackers' attacks on political actors' and parties' websites, portals of state bodies;

- such political provocations as technologies of "black PR" (creation of clone-sites, dissemination of false information) (Voynov, 2016, p. 50).

The analysis of political activity and participation phenomena provided in this study is 
based on the above-mentioned disclosure of political participation and its methods and ways listed above.

To achieve the target set in the article, content analysis of documents (publications in the mass media), monitoring of Facebook and consequential analysis of research in this field have been held.

Already in the 2000s, the Internet began to assume an essential role in the public life of postSoviet countries. For instance, in 2005 Estonia held elections to local bodies through the Internet for the first time in Europe. More than 9 thousand citizens or about $1 \%$ of those eligible to vote took advantage of voting through the Internet. That number has been incessantly increasing during the following years. Since 2005, 6 electronic elections have been held in Estonia. And a sweeping number of citizens, $43.8 \%$ of the electors were eager to vote via the Internet at the 2019 elections to Estonia's National Assembly (The Riigikogu is the unicameral parliament of Estonia) (Valimised, 2019).

Almost all forms of political participation via the Internet were employed during the 2018 "Velvet Revolution" in Armenia. The opposition leader N. Pashinyan used his FB personal page to inform the public and to improve their political activeness.

It should be noted that most local TV and radio companies were to some extent under the control of the former authorities or their associates. The Internet remained the only means for information about non-violent demonstrations and for stimulation of active participation of broad masses. Perhaps, if it weren't for the Internet, a large number of FB-users (1.2 million) and wide coverage of the Internet throughout Armenia, the "Velvet Revolution" would hardly have come true.
The protest leader Nikol Pashinyan notes regarding this issue: "Currently my Facebook page has a huge audience comparable to that of a $\mathrm{TV}$ audience. This is a rather effective means for dialogue with the public and citizens. Facebook definitely played a big role in the process of our revolution and was a very effective channel for information flows to invite people to demonstrations" ("Deutsche Welle", 2018).

This is a new phenomenon and a new culture of political participation in Armenia. The authorities never used to apply the Internet to transmit urgent information to the public. Before the "Velvet Revolution," FB was more a forum for analyses and personal information. Many government members, especially young ones, had their personal FB pages; however, Internet activity wasn't considered anything very positive by most of the public. Sceptical approach towards the FB forum was also drastically reviewed after the 2018 change of government. In August 2018 R. Kocharyan, the second RA President also created his personal page; representatives of the former authorities began to present their messages to the public via FB as well.

The leader of the "Velvet Revolution" N. Pashinyan gave live reports every hour about the march that commenced on March 31 and resulted in revolutionary events just three and a half weeks later. Monitoring of his FB page proves that his page became 72 times more active within two weeks. During the first five days of the march, his live messages were viewed 31345 times on average, while during the last five days the figure reached 225651 . The most powerful tool in the hands of the opposition at the time was Internet communication. With the help of Internet monitoring opposition figures were able to point out the issues mostly worrying the crowds that had taken to the streets. Thus, they 
were able instantly to change slogans, namely: "I am making my step", "Anti-Sashik", "Make a step, deny Serj", "Help Serj to retire", "Policeman, join in", "Policeman is one of us", etc.

At that moment the TV as a source of information was upstaged because, before it was able to process the available information, the situation in the country would change, events developed in some unpredictable way and rather quickly. Live broadcasts from Internet media and FB users remained the main source of updated, latest and first-hand information.

After the opposition leader assumed the post of the Prime Minister, TV programs presented live broadcasts from his FB page, which had no precedent during the former authorities.

Results of the syndicative sociological survey conducted by Gallup International organization a month before the parliamentary elections of 2017 April and 2018 December also prove the decline of the role of TV.

The data of surveys held within 1.5 years show that TV has lost its position as a primary source of information by $14.7 \%$. The number of people acquiring information from the TV has reduced, while the number of those gaining information from Facebook and e-media has increased by $13 \%$ and $10.4 \%$ respectively ("Gallup Int. Co", 2017; 2018).

Hence, $84.2 \%$ of the respondents mentioned TV, 24.7\% Facebook and 18\% e-media as the main source of information on political processes during the poll carried out in 2017 ("Gallup Int. Co", 2017).

While the same question concerning what source is the main to get information on political processes of the 2018 poll displays that $69.5 \%$ of the respondents mention TV, 37.7\% Facebook and $28.4 \%$ e-media (“Gallup Int. Co", 2018). See Diagram 1.

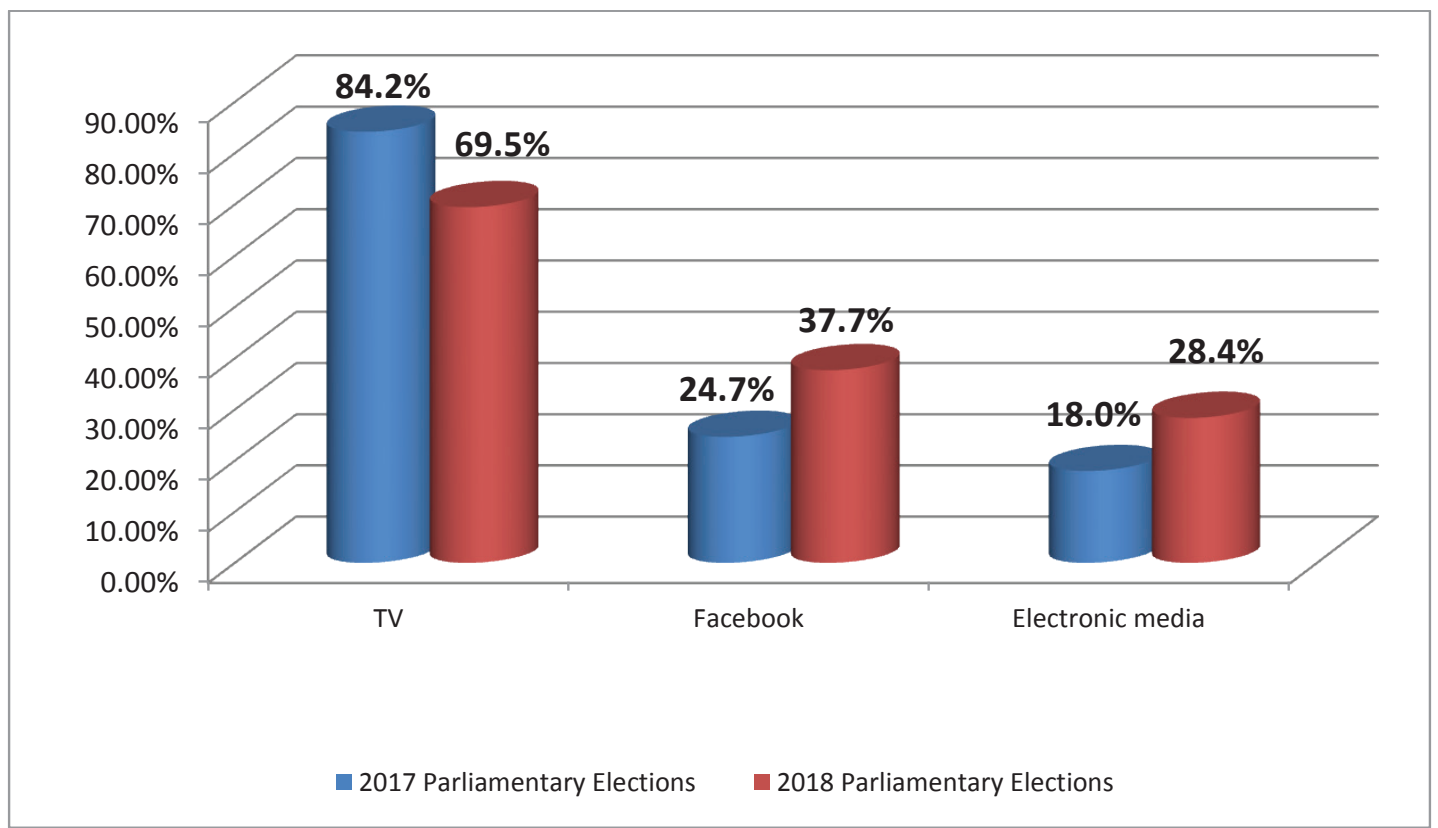

Diagram 1. Main sources of information prior to elections to the parliament of the 6 th and 7 th convocation.

Implementation of the Internet in politics promotes the evolution of the conventional par- ticipatory model. The consultative model of political participation is being replaced by the inter- 
active model providing the impact of broad masses on the decision making in political processes. However, the influence of the Internet on political events varies from country to country, depending on national, cultural characteristics (Avzalova, 2015, p. 191).

Internet political participation contributes to the elimination of vertical contacts in communication processes and to the formation of horizontal political institutes-public relations. The genesis of the democratic, participatory model can be traced in the RA since the turnover of 2018 spring. The newly elected authorities are rather sensitive about the communication on the Internet platform. They not only present reports on the work fulfilled, but also follow the feedback of the society.

Thus, political participation via the Internet has its advantages and characteristic features. Firstly, Internet participation gives an opportunity to overcome time, distance and geographic obstacles, an example of which we witness during the spring-summer months of 2018 in Armenia when citizens, independent of their place of residence, watched the political movement in action in the country and integrated into the events following the opposition leader's all instructions. The crowd mobilized instantly and impeded traffic, held demonstrations and strikes and other acts of civil disobedience.

Another major function of the Internet gives a citizen the opportunity to impact the process of making decisions on significant issues of public importance. In some cases, representatives of the newly elected government address the public: on their FB page they raise the issue and ask the public what solution they see in that definite situation. There are also cases when some decisions are reviewed or suspended after they have been sharply criticized on the Internet by society.
In other words, Internet participation provides feedback between the authorities and the public.

The political phenomenon with acquired features of horizontal communication is transforming into a multi-component, multi-faceted interactive form of political communication.

Although any powerful weapon (like the energy generated when an atom is split) may have a positive implementation, promote resolution of problems and advance of civilization, it may just as well be employed erroneously and produce disastrous effects. In the $18^{\text {th }}$ century, Jan Jack Russo noticed that development of science and technology contains inherent consequences menacing to the progress of society and the person. The issue has been relevant at all times, including today (Russo, 2014).

In this context, the person who created these technologies assumes an essential role with his moral outlook and value problems; meanwhile voicing and regulation of the latter, as the history of civilization shows, "lag behind" scientific and technical revolutions. Neutralization of abuses and risks of capabilities of continually developing technologies supposes not only philosophical consideration but also moral and legal studies and practical mechanisms.

And yet, development of science and technologies is indivertible; it has no alternative and is to serve the wellbeing of man, enhancement of democracy. The study of the above-mentioned influence of information technology on the social, political, economic, educational and cultural spheres of public life bearing not only theoretical and emotional but also practical importance.

\section{REFERENCES}

Avzalova, E. I., (2015). Internet-uchastie kak novaya forma politicheskogo uchastiya 
grazhdan (Internet-Participation as a New Form of Citizens' Political Participation, in Russian). Journal "Scientific notes of Kazan University”, 157(1), 187- 193.

Chadwick, A., \& May, C. (2003, April). Interaction between States and Citizens in the Age of Internet: «e-Government» in the United States, Britain and the European Union. An International Journal of Policy, Administration, and Institutions "Governance”, 16(2), 159-311.

Ekman, J., \& Amna, E., (2012). Political Participation and Civic Engagement: Towards a New Typology. Human Affairs, 22(3), 283-300. Retrieved April 19, 2019 from: doi:10.2478/s13374012-0024-1.

Grossman, L. K., (1995). The Electronic Republic: Reshaping Democracy in the Information Age. New York: Viking Penguin.

Rousseau, J.-J., (2014). Discourse on the Arts and Sciences. (I. Johnston, Trans.). South Australia: The University of Adelaide Library. Retrieved April 19, 2019, from: https://ebooks.adelaide. edu.au/r/rousseau/jean jacques/arts/.

Sargsyan, T. S., (2008). Petut'jan vaxtwany' (The End of the State, in Armenian). $21^{\text {st }}$ Century, 1(19), 3-26.

Vasilik, M. A. (Ed.) (2000). Politologiya (Politi- cal Science, in Russian). Moscow: Gardariki.

Voynov, D. A., (2016). Politicheskie internetkommunikatsii: samoupravlenie vs kontrol' (Political Internet Communication: Self-Governance vs Control, in Russian). Age of Quality, 1, 48-57. Retrieved April 19, 2019, from http://viperson.ru/wind.php?ID=63049 $\underline{6 \& \text { soch }=1 .}$.

\section{SURVEY REPORTS AND OTHER SOURCES}

Barlow, J. P., (1996). A Declaration of the Independence of Cyberspace. Retrieved April 19, 2019, from https://www. eff.org/ru/cyberspace-independence.

Deutsche Welle. (2018). Nikol Pashinyan: Facebook Played an Important Role in the Revolution in Armenia. May 29.

Gallup International in Armenia. National Assembly Elections 2017. Political Parties and Alliance Indicators till March 20. PMG-Report 02/2017. Yerevan.

Gallup International in Armenia. Parliamentary Expression. Starting Station. PMG-Report 11/2018. Yerevan.

Valimised. (2019). Retrieved April 19, 2019 from: https://rk2019.valimised.ee/ru/vot ing-result/voting-result-main.html. 